\title{
Librarians and Information Centers
}

\author{
BY ALAN M. REES
}

THE INCREASING COMPLEXITY of modern civilization, the advent of the space age, and the consequent added significance of recorded knowledge have presented a serious challenge to the traditional practice of librarianship. The bibliographical apparatus and tradition of library service so carefully created and nurtured for many decades have been severely tested by the demand for rapid access to vast stores of highly complex and diversified information. The traditional tools of the librarian have been critically scrutinized and in many instances rejected by innovators who wish to create and systematize a more powerful and flexible information technology. The dependence of society on recorded knowledge is such that it is not surprising that radical and often intemperate solutions hold an appealing charm. The conservatism of librarianship, whether a result of the humanistic tradition or of other factors, has fanned the ardor with which innovators wish to break with traditional practices. The very ability of the librarian to adjust to a new industrialized and automated era has been questioned since it is "immaterial to society whether its thirst for recorded knowledge is quenched by librarians or by some new professional breed."1

Response on the part of librarianship to the information needs of a changing society necessitates consideration of both means and ends-the efficiency of the technological means (traditional and nonconventional) for accomplishing present library objectives; and the definition of the objectives themselves. The former will be discussed in relation to informa-

\footnotetext{
1 Jesse H. Shera, "Little Girls Don't Play Librarian," Library Journal, LXXVII (December 15, 1962), 4486.
}

Mr. Rees is Assistant Director, Center for Documentation and Communication Research, and Assistant Professor, Library Science, Western Reserve University.

tion retrieval and the latter with reference to specialized information centers, since information retrieval represents alternative means of achieving current library objectives, whereas the information center concept is based upon marked differences in objectives.

\section{LIBRARIANSHIP AND INFORMATION RETRIEVAL}

The so-called schism between library science and information retrieval has been grossly exaggerated. Although it is somewhat fascinating to debate the comparative merits of variants in indexing techniques, relative speeds of search, complexity of search prescriptions, relevance and recall of search output of computerized information retrieval systems versus traditional library based practices, it must be recognized that we are considering nothing more than the merits of alternative means of achieving common ends. Excessive attention to the engineering aspects of librarianship should not lead to a confusion of means with ends. The avowed aim of librarians is to provide documents which contain relevant information, or in some limited cases the information itself. Likewise, the advocates of mechanized retrieval systems offer titles, bibliographies, abstracts, and relevant documents.

A decade of debate has neither proved nor disproved the alleged superiority in terms of effectiveness and efficiency of 
computerized over manual retrieval systems. No demonstrable proof has been advanced to define at what point in the operation of a traditional library system it is expedient to mechanize or under what circumstances the choice of a computerized system is preferable to that of a manual system. Test methodology to establish the comparative performance of systems is still in an experimental stage.

Moreover, coordinate indexing, descriptors, thesauri, and other devices deriving from information retrieval technology represent nothing new to librarianship. The theoretical basis of the thesaurus, for example, can in no manner be sharply differentiated from principles long known to librarians. The successful performance of the thesaurus over that provided by classification and subject headings has not been demonstrated in any systematic manner. In fact, the available evidence seems to point in the other direction. $^{2}$

In short, the contributions of the innovators have not been held up to adequate scrutiny and evaluation. Differences have been emphasized, rather than similarities. The old wine poured into new bottles has not been labeled by librarians as the same old stuff. The argument with respect to technological detail has been barren and unsubstantiated and has detracted from consideration of the important matter of what librarians should be doing, rather than how they should do it. Systems analysis and experimentation will eventually yield quantitative data with respect to the efficiency of alternative means, but this can hardly replace the "somewhat shopworn dreams of the giants of our field in the nineteenth century"3

\footnotetext{
2 Jean Aitchison and Cyril Cleverdon, "A Report on a Test of the Index of Metallurgical Literature of Western Reserve University," College of Aeronautics, Cranfield, England, October 1963; Cyril Cleverdon and J. Mills, "The Testing of Index Language Devices," ASLIB Proceedings, XV (April 1963), 106-30.

${ }^{3}$ Ralph R. Shaw, "The Library's Role in Society Today," Journal of Education for Librarianship, II (Spring 1962), 182.
}

with objectives more appropriate to the modern world.

\section{The Information Center Concept}

The principal issue facing librarianship relates to objectives. The rapid proliferation of specialized information centers, ${ }^{4}$ many of which do not utilize electronic searching equipment, illustrates the point that the essential differences between librarianship and the newer concepts of information handling relate more to the type and extent of information services offered to the user than to the techniques employed to describe, store, and retrieve documents.

The increasing acceptance of the information center concept is proof that information services which go beyond the librarian's traditional conception of reference service are required and demanded. Already the role of the librarian is being usurped by the large number of persons engaged in information handling outside of the library. The information center therefore represents a more serious challenge to librarianship than was ever posed by the appearance of the computer on the library scene.

The information center concept is based upon several assumptions. The transfer of information is considered to be more complex than the acquisition, storage, and retrieval of documents as

It is necessary at this point to indicate that I accept the definition of specialized information centers advanced by G. S. Simpson: "A scientific information center exists for the primary purpose of preparing authoritative, timely and specialized reports of the evaluative, analytical, monographic, or stateof-the-art type. It is an organization staffed in part with scientists and engineers, and to provide a basis for its primary function, it conducts a selective data and information acquisition and processing program." American Documentation, XIII (January 1962), 43. This definition can be supplemented by that of Cohan and Craven, who consider that an information center represents the unification of "library, patent, translation, report writing, archival, abstracting, literature research, editorial, communications, and publication activities within a single information facility." Leonard Cohan and Kenneth Craven, "Science Information Personnel," (New York P.O. Box 624, Radio City Station: 1961), p.11. I in no way consider special libraries as information centers even though they may designate themselves as such. 
the physical repositories of information. Storage and retrieval are only a part of the total information transfer chain which extends from the generation of the information itself to the ultimate utilization of the information by users. The excessive emphasis upon retrieval as such and accompanying mechanical aids does not recognize the fact that many information services are cluttered with redundant, useless, and inconsequential trivia which should never have been written, let alone incorporated into a retrieval system. The flood of scientific publication is so great that "scientific information centers are necessary to reduce, analyze and shrink to manageable proportions all such data and information."

A further assumption is that document retrieval cannot be equated with information retrieval. "A pile of documents on a manager's or researcher's desk is of little use; it is information he needs." The user is consequently not informed but is "overwhelmed with a pile of reports instead of a concise answer to a question." The information center offers selected, specific, and synthesized information derived from a carefully preselected store of documents.

A sharp distinction is made between such centers and libraries. The whole spirit and tradition of librarianship, it is argued, has been dominated by the notion that the librarian's primary task is to connect the user with documents which contain the information he is seeking and that librarians either will not, or cannot, go beyond the furnishing

\footnotetext{
${ }^{5}$ G. S. Simpson, op. cit., p.48.

6 Jerome B. Wiesner, in Surgeon General's Conference on Health Communications, November 5-8, 1962 , U.S. Department of Health, Education and Welfare, Public Health Service Publication No. 998, p.95. See also D. J. Foskett, Classification and Indexing in the Social Sciences (London: Butterworth's, 1963), p.5 : ". . . there is a useful and valid distinction to be made between examining the literature to see whether it contains any information that appears to be relevant to a given topic, and actually studying the literature thus selected to decide whether its information has value for one's own research. The establishment of relevance is not the same as the establishment of value."
}

of documents. Since information and documents are not identical, the librarian is providing addresses of information and not information itself. Document retrieval is therefore only "a prerequisite to information retrieval and an information retrieval system that stops short of transferring information from one human mind to another is inadequate." $"$ The problem therefore involves the transfer and dissemination of information and not just the retrieval of relevant documents.

The traditional role of the librarian has in fact been confined to document handling, and techniques have accordingly been developed to describe documents in suitable indexing languages to permit subsequent retrieval of abstracts of documents or possibly the documents themselves. The information center emphasizes information processing and the dissemination of information derived from documents. Users are furnished with processed information in an assimilable form with direct and explicit relationship to their research interests.

The information center is a "technical institute, not a technical library. It differs from a library in that those who operate the specialized information center are expected to know, in the usual manner that a scientist knows, the contents of the material contained in the center." Information is processed by information specialists in a manner which is alien to the technical library in that the "input of the specialized information center is documents and uncorrelated data; its output is reviews, correlated data, compilations."

The user of the information center differs from the library patron in the degree of delegation which he is willing to

\footnotetext{
"Alvin Weinberg, "Seience, Government and Information," Preprint of an article in International Science and Technology, March 1963, pp.4, 5.

${ }^{8}$ Ibid., p.5. See also "Science, Government and Information: the Responsibilities of the Technical Community and the Government in the Transfer of Information." A Report of the President's Science Advisory Committee, The White House, January 10 , 1963. (This is known popularly as the Weinberg Report.)
} 
assign. In the case of library based reference service, the user delegates the task of searching to a trained reference librarian who furnishes the question-asker with a list of relevant documents in the form of titles, abstracts, or possibly the actual documents. The question-asker approaching the information center delegates not only the search function but also much of the judgment involved in selecting information appropriate to his information needs. He therefore assigns the task of reading, digesting, selecting, critically evaluating, and synthesizing information derived from documents and relating the information to the specific information need which initiated the question. Judgment as to the significance of search output is therefore exercised.

The information center therefore differs from the library with respect to four main points:

1. Degree of delegation on the part of the information requester.

2. Exercise of judgment and evaluation as to the significance and merit of the identified documents relative to the information needs of the requester.

3. Provision of information and not documents.

4. Processing of search output into a variety of search products-state-ofthe-art review, critically compacted data, digests, and so on.

\section{LIBRARIANS AND INFORMATION CENTERS}

The somewhat rigid differentiation between librarianship and the information center concept represents a present trend in the development of information services. It does not, however, imply that this polarization is desirable or inevitable. Moreover, some special libraries do indeed furnish selected information and thereby approximate the services of information centers; conversely, many information centers provide documents with only limited processing of information. ${ }^{9}$

Within librarianship there is an increasing awareness of the role of the librarian in the total information transfer chain. The Special Libraries Association recently scheduled a panel discussion on the Weinberg Report at the association's annual convention. ${ }^{10}$ Rothstein considers that "reference service represents a new dimension in librarianship" and that the "chief pattern now is to decide on the proper dimensions of that service."11 "Both the needs of our clients and our own self-interest say that we should look for ways to work at greater range and depth, to do always more and not less."12

The history and development of reference service and special librarianship make the function and scope of the specialized information center the natural birthright and responsibility of the library profession. In the same manner that reference service as presently understood replaced the older concept of "access to librarians" and "aid to readers" the provision of synthesized information extracted from documents or the compilation of the state-of-the-art review is a natural extension of reference work. "The modern librarian," wrote Dewey in 1885 , "is active and not passive. He is as glad to welcome a reader as the merchant a customer ... he magnifies his office and he recognizes in his profession an opportunity for usefulness to his fellows inferior to none."13

\footnotetext{
'As of November 1961 there were 427 information centers listed in the National Science Foundation Directory of Specialized Science Information Services in the United States. This does not include many classified centers within such agencies as the Department of Defense. Not all centers listed can, however, be considered as such, since they are not centers according to the definition eited above.

10 "Special Librarians and the Weinberg Report," Special Libraries, LIV (July-August 1963), 325-32.

11 Samuel Rothstein, "Reference Service: the New Dimension in Librarianship," College and Research Libraries, XXII (January 1961), 12.

${ }^{12}$ Ibid., pp.17-18.

${ }^{13}$ Quoted by Samuel Rothstein in The Development of Reference Services through Academic Traditions, Public Library Practice and Special Librarianship (ACRL Monograph, No. 14 [Chicago: ACRL, 1955]), p.25.
} 
The services of the information center can therefore be viewed as the most developed point of a continuum which began in 1865 with the publication of Samuel Swet Green's paper, "The Desirableness of Establishing Personal Intercourse and Relations Between Librarians and Readers in Popular Libraries." Simpson, the leading exponent of the information center concept, concedes that "conventional libraries were sufficient up to the twentieth century. Specialized libraries then developed to supply services not available from conventional libraries. Specialized information centers are but an extension of that trend." 14

The rapid rise and increasing acceptance of such centers can in large part be attributed to the unwillingness of special librarians to provide new dimensions in reference services. A whole spectrum of information services can be identified which range from the provision of specific documents, answering of "spot" questions, conducting of bibliographical searches to the synthesized state-of-the-art review. At the far end of this spectrum the librarian would be an active participant in the research process, rather than an interested bystander with his hands full of printed text.

It is hardly possible for librarians to maintain that the responsibility for the establishment, operation, and management of information centers does not rest within librarianship. The information center concept should be used to "advance our own programs of making our libraries more closely satisfy the total information requirements of our organizations." ${ }^{15}$ It is hardly flattering for special librarians to be informed that, unlike libraries, information centers are user-oriented; handle data rather than documents in many instances; operate at the information fron-

\footnotetext{
14 Simpson, op. cit., p.48.
}

15 Winifred Sewell, in "Special Librarians and the Weinberg Report,"' Special Libraries, LIV (JulyAugust 1963), 331. tier; and have highly selective and aggressive acquisition programs. ${ }^{16}$

One can only conclude that librarianship cannot permit the abnegation of the traditional function of the librarian-to satisfy the information needs of clientele. It is not possible for librarianship to slough off the responsibility of catering to the highly specialized and rapidly changing information needs of scientists and engineers. A new breed of librarians will be required, possessing both scientific knowledge and training in the application of appropriate and proved information handling techniques. The significance of adequate educational programs in this connection cannot be overemphasized. ${ }^{17}$ The future librarian must be concerned with the total information problem and must be as expert in the evaluation, selection, dissemination, and presentation of information as in the techniques of storage and retrieval.

A recent writer proposes an "openskies system of library service which will be conspicuously outgoing, steadfastly oriented towards use and unquestionably effective. And with this achievement will come honor, and glory, and status, and power, and money, and a far larger share of the academic kingdom. But we must justify our existence-it will be no giveaway." 18 A new definition of library objectives is necessary before the implementation can begin. No amount of discussion with respect to technological detail can achieve this for librarianship.

\footnotetext{
16 Walter M. Carlson, Director of Technical Information in the Department of Defense recently observed that, "within the broad pattern of scientific and technical information, the research libraries and their associated staffs are fitting effectively into a rather clearly defined role-a role in which they serve a primarily archival function and are mainly concerned with the published literature. Special Libraries, IV (January 1964), 14.

${ }^{17}$ Alan M. Rees, "New Dimensions in Library Education-The Training of Science Information Personnel," Special Libraries, LIV (October 1963), 497 502. See also Jesse H. Shera, "Toward a New Dimension in Library Education," ALA Bulletin (April 1963), 313-17.

18 Neal Harlow, "Open-Skies System of Library Service," Journal of Education for Librarianship, II (Spring 1962), 189.
} 